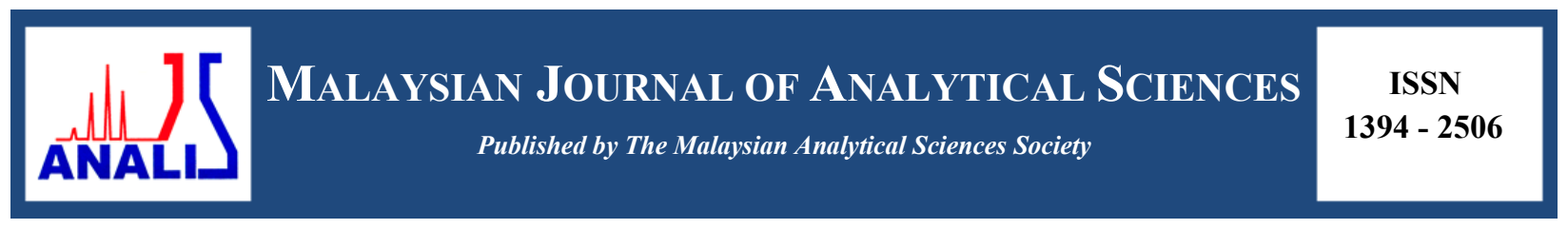

\title{
ENCAPSULATION OF GADOLINIUM NANOPARTICLES IN AMINO ACID BASED VESICLES
}

\author{
(Pengkapsulan Nanozarah Gadolinium ke dalam Vesikel Berasaskan Asid Amino)
}

\author{
Muhammad Zul Azri Muhammad Jamil, Faizal Mohamed*, Nur Ratasha Alia Md. Rosli, Irman Abdul Rahman \\ Nuclear Science Programme, School of Applied Physics, \\ Faculty of Science and Technology, \\ Universiti Kebangsaan Malaysia, 43600 UKM Bangi, Selangor, Malaysia \\ *Corresponding author: faizalm@ukm.edu.my
}

Received: 18 April 2017; Accepted: 12 September 2017

\begin{abstract}
Production of amino acid based vesicles using sonication method was employed to determine its encapsulation efficacy towards gadolinium(III) nanoparticles as potential drug carrier. The sonication process involved precursor namely sodium $\mathrm{N}$ lauroylsarcosinate hydrate with 1-decanol to produce vesicle in $92 \mathrm{wt} \%$ of water. Gadolinium(III) nanoparticle was then encapsulated into the vesicle system. The structure of $\mathrm{Gd}_{2} \mathrm{O}_{2} \mathrm{CO}_{3}$ nanoparticles was confirmed by X-ray Diffraction technique (XRD). Attenuated Total Reflectance Fourier Transform Infrared (ATR-FTIR) spectroscopy indicates the presence of bonding that formed the vesicles. The size distribution of the obtained gadolinium encapsulated vesicle was examined using Transmission Electron Microscopy (TEM). It has been proven to be a potential nano-sized drug carrier.
\end{abstract}

Keywords: vesicles, encapsulation, gadolinium, sonication, drug carrier

\begin{abstract}
Abstrak
Penghasilan vesikel berasaskan asid amino menggunakan kaedah sonikasi telah digunakan dalam menentukan pengkapsulan nanozarah gadolinium(III) yang berpotensi sebagai pembawa dadah. Proses sonikasi melibatkan prekursor natrium Nlauroylsarkosinat hidrat dengan 1-dekanol untuk menghasilkan vesikel dalam 92 wt.\% air. Nanozarah gadolinium(III) kemudiannya dikapsulkan ke dalam sistem vesikel. Struktur nanozarah $\mathrm{Gd}_{2} \mathrm{O}_{2} \mathrm{CO}_{3}$ telah disahkan menggunakan teknik pembelauan sinar-X (XRD). Spektroskopi transformasi infra merah Fourier (ATR-FTIR) menunjukkan kehadiran ikatan yang terbentuk ke atas vesikel. Taburan saiz yang nanozarah gadolinium terkapsul ke dalam vesikel dilihat menggunakan mikroskop elektron trasmisi (TEM). Ia telah terbukti berpotensi sebagai pembawa dadah bersaiz nano.
\end{abstract}

Kata kunci: vesikel, pengkapsulan, gadolinium, sonikasi, pembawa dadah

\section{Introduction}

Nanomedicine is defined as a material used for specific diagnostic or therapeutic purposes in the scale range of 1100 nanometers [1]. These therapeutic carriers have been increasingly used as drug delivery vehicles for the vast advantages that they offer due to their small size and versatility [2]. Gadolinium nanoparticles are very important as nuclear, phosphor, optical and electronic material [3-5]. Gadolinium is another new class of radiation sensitizers [6] because they could be easily viewed in vivo through the use of magnetic resonance imaging (MRI). MRI is a popular technique because it has a good soft tissue contrast [7] and high spatial resolution with non-invasive in vivo visualization [8]. In clinical use, the size of the nanoparticles has to be small to limit the toxicity due to poor renal clearance which is $6 \mathrm{~nm}$, in order to allow complete and exclusive renal elimination after intravenous injection [9]. 
Vesicle has already been proven to be important as carrier system and for studying basic biology and medicine related to cell membranes [10]. Vesicle is a bilayer membrane structure consisting of a closed fluid chamber encapsulating aqueous solution $[11,12]$. The vesicles were proven to have a good characteristic and potential as a drug delivery vehicles or carrier $[13,14]$. In the present investigation, our goal is to encapsulate the gadolinium nanoparticles with amino acid based vesicle. The samples were characterized with various instruments such as transmission electron microscopy (TEM), Fourier transform infrared spectroscopy (FTIR) and X-ray diffraction (XRD).

\section{Materials}

\section{Materials and Methods}

Sodium N-lauroylsarconate with 95\% purity was purchased from Across Organics (New Jersey, United States of America), 1-Decanol with 99\% purity was purchased from Sigma-Aldrich and Nitric acid with $69.0-70.0 \%$ purity was purchased from J.T.Baker (Thailand). Gadolinium(III) oxide carbonate was purchased from Sigma-Aldrich with $99.8 \%$ trace metals basis. Deionized water was used to prepare all samples.

\section{Synthesis gadolinium(III) nitrate solutions}

In order to obtain mixed assemblies, the required amount of $\mathrm{Gd}_{2} \mathrm{O}_{2} \mathrm{CO}_{3}$ was dissolved in $\mathrm{HNO}_{3}$ to form $5 \mathrm{~mol} / \mathrm{L}$ concentration of nitrate solution. $0.1 \mathrm{ml}$ nitrate solution was diluted with $500 \mathrm{ml}$ deionized water. The $\mathrm{pH}$ of mixture was monitored and adjusted to $\mathrm{pH} 5$ using deionized water. From this stock solution, only $0.08 \%$ of nitrate solution was used to synthesize amino acid based vesicles.

\section{Synthesis of control amino acid based vesicle}

Amino acid based vesicles were prepared according to the sonication method as reported previously by Akter et al. [15] and Rosli et al. [13] with several modification. Sodium N-lauroylsarcosinate hydrate was mixed with 1-decanol in a test tube at a molar ratio of 1:2 in $92 \mathrm{wt} \%$ of deionized water. The solution was sonicated for 15 minutes at room temperature using a bath sonicator. To obtain micro emulsion, the solution was vortexed for 5 minutes at 1400 $\mathrm{rpm}$. The solution was then centrifuged for 15 minutes at the speed of $4200 \mathrm{rpm}$ to obtain phase separation. The samples were left undisturbed for a few hours to achieve equilibrium.

\section{Synthesis of vesicle encapsulating gadolinium(III) nitrate nanoparticles}

Vesicle encapsulating gadolinium (III) nitrate nanoparticles was synthesized using the same method used to synthesize control amino acid based vesicle with minor modification, in which the encapsulated gadolinium(III) nitrate nanoparticles was added to the deionised water prior to its addition with surfactant (SNLS and 1-decanol).

\section{Characterization study}

To identify crystalline products, X-ray diffraction (XRD) pattern were collected on a Bruker D8 Advance, using $\mathrm{Cu}$ $K \alpha 1$ radiation $(40 \mathrm{kV}, 40 \mathrm{~mA})$ with a wavelength 1.54060 in $2 \theta$. Attenuated total reflectance infrared (ATR-FTIR) spectra in transmission mode were measured on a Perkin Elmer FTIR Spectrum 400 spectrometer in determining molecular confirmation using pressed $\mathrm{KBr}$ tablets in a mortar. The formations of vesicles were characterized using a transmission electron microscope (TEM, Bruker HT7700 electron microscope, operated at $120 \mathrm{kV}$ ).

\section{X-ray diffraction}

\section{Results and Discussion}

Based on the $x$ ray diffraction patterns of powdered nanoparticle $\mathrm{Gd}_{2} \mathrm{O}_{2} \mathrm{CO}_{3}$ in Figure 1, three dominant peaks of hexagonal $\mathrm{Gd}_{2} \mathrm{O}_{2} \mathrm{CO}_{3}$ are observed. These peaks consist of peak 250 (at $2 \theta \approx 31.8^{\circ}$ ), peak $175\left(\right.$ at $2 \theta \approx 27.0^{\circ}$ ) and peak 115 (at $2 \theta \approx 46.4^{\circ}$ ). These findings indicated that the nanocrystals consist of crystalline $\mathrm{Gd}_{2} \mathrm{O}_{2} \mathrm{CO}_{3}$ with an excellent peak fitting (JCPDS no. 00-038-0680). 


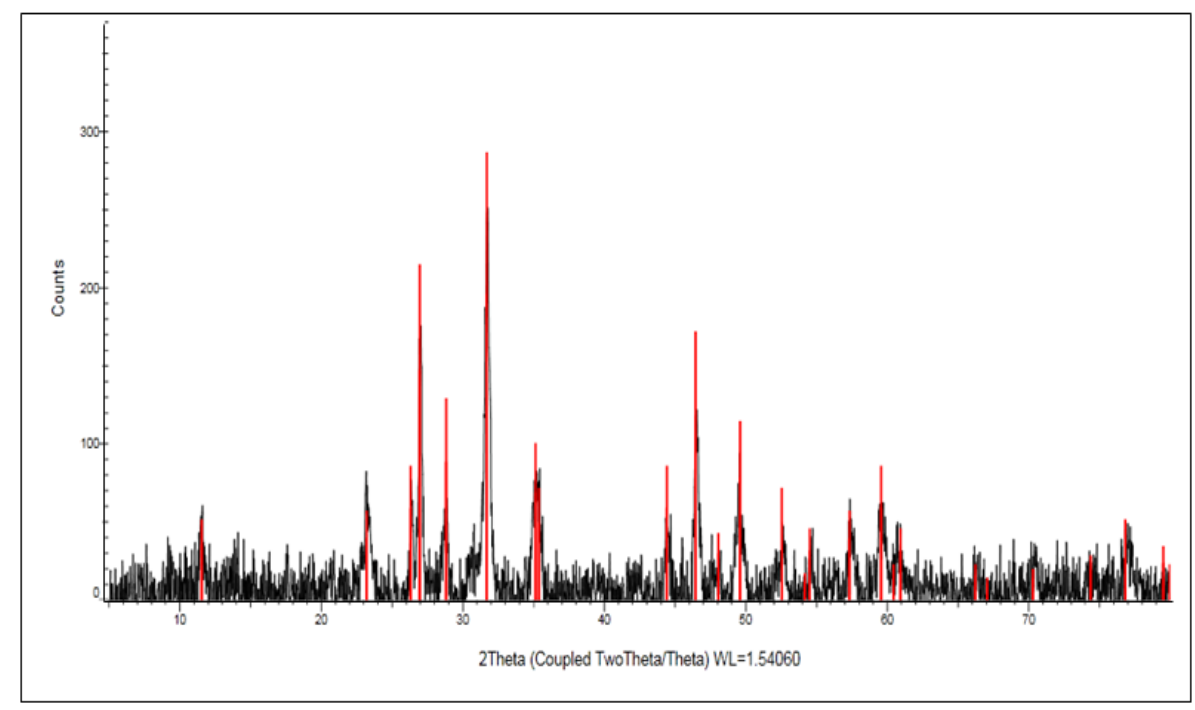

Figure 1. X-ray diffractograms of powdered $\mathrm{Gd}_{2} \mathrm{O}_{2} \mathrm{CO}_{3}$ nanoparticles

\section{Fourier transform infrared spectroscopy}

The characterization of nanoparticles was performed using FTIR at a wavelength between $500 \mathrm{~cm}^{-1}$ to $4000 \mathrm{~cm}^{-1}$. The IR spectrum of $\mathrm{Gd}_{2} \mathrm{O}_{2} \mathrm{CO}_{3}$ and $\mathrm{Gd}\left(\mathrm{NO}_{3}\right)_{3}$ nanoparticles are shown in Figure 2. The chemical bonds and functional group present in the characterized sample are as listed in Table 1. The peaks at 1100 and $860 \mathrm{~cm}^{-1}$ represent carboxylic acids functional group $(\mathrm{O}-\mathrm{C})$ and $(\mathrm{C}-\mathrm{O}-\mathrm{H})$ of $\mathrm{Gd}_{2} \mathrm{O}_{2} \mathrm{CO}_{3}$, respectively. The alkene functional group of the $\mathrm{Gd}_{2} \mathrm{O}_{2} \mathrm{CO}_{3}$ nanoparticles are also present at peak $1400 \mathrm{~cm}^{-1}\left(=\mathrm{C}-\mathrm{H} \&=\mathrm{CH}_{2}\right.$ stretch $)$. Furthermore, a (CC) stretch (in-ring) of $\mathrm{Gd}_{2} \mathrm{O}_{2} \mathrm{CO}_{3}$ appears as a very strong and sharp peak at $1490 \mathrm{~cm}^{-1}$.

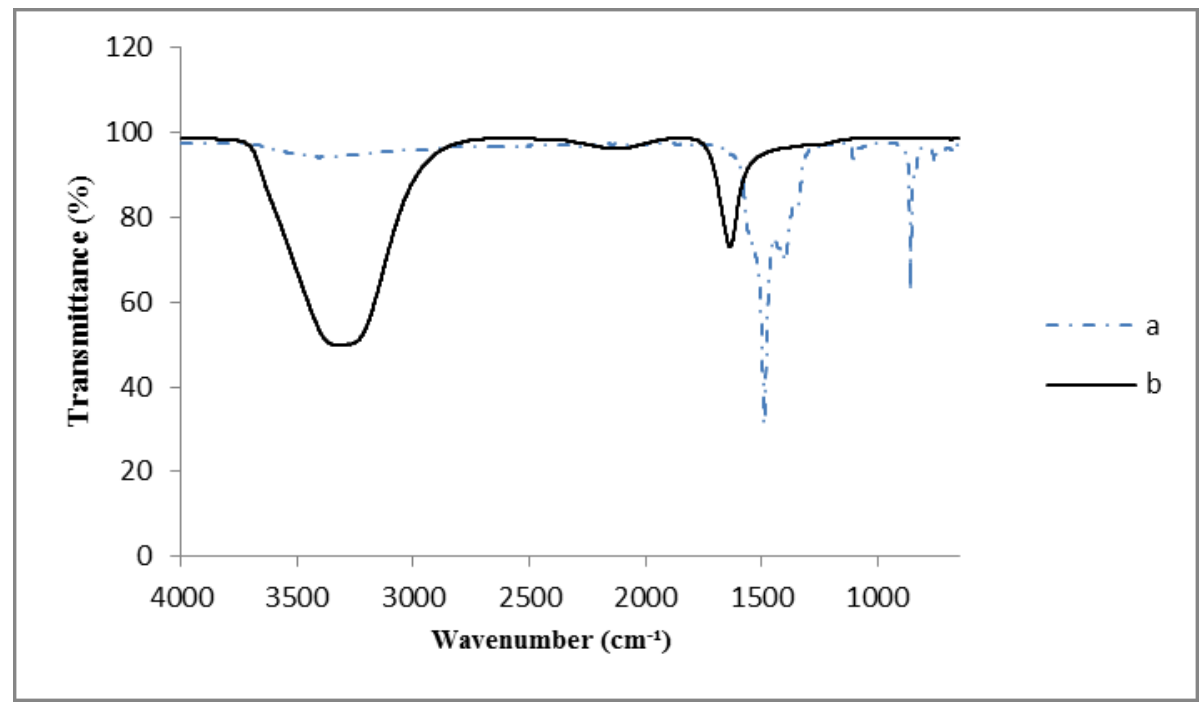

Figure 2. FTIR spectrum of (a) $\mathrm{Gd}_{2} \mathrm{O}_{2} \mathrm{CO}_{3}$ powder and (b) $\mathrm{Gd}\left(\mathrm{NO}_{3}\right)_{3}$ solution. 
Table 1. Vibrational mode assignment of $\mathrm{Gd}_{2} \mathrm{O}_{2} \mathrm{CO}_{3}$ particles and $\mathrm{Gd}\left(\mathrm{NO}_{3}\right)_{3}$ solution

\begin{tabular}{llcc}
\hline \multirow{2}{*}{ Modes of vibration } & \multirow{2}{*}{ Functional group } & \multicolumn{2}{c}{ Wavenumber $\left(\mathbf{c m}^{-\mathbf{1}}\right)^{-}$} \\
\cline { 3 - 4 } & & $\mathbf{G d}_{\mathbf{2}} \mathbf{O}_{\mathbf{2}} \mathbf{C O}_{\mathbf{3}}$ & $\mathbf{G d}\left(\mathbf{N O}_{\mathbf{3}}\right)_{\mathbf{3}}$ \\
\hline O-H stretch (wide,strong) & Hydroxyl & 3406.09 & 3330.65 \\
$\mathrm{C} \equiv \mathrm{N}$ stretch & Nitriles & n.d & 2123.61 \\
$\mathrm{C}=\mathrm{O}$ strecth (strong) & Amides & n.d & 1636.80 \\
H-C-H bend & Alkane & 1488.26 & n.d \\
C-O strecth & Ether & 1395.45 & n.d \\
C-N strecth & Aliphatic amines & 1104.94 & n.d \\
\hline
\end{tabular}

${ }^{\text {n.d }}$ Not detected

Besides that, based on the spectrum obtained, $\mathrm{C} \equiv \mathrm{N}$ stretch and $\mathrm{C}=\mathrm{O}$ stretch of $\mathrm{Gd}\left(\mathrm{NO}_{3}\right)_{3}$ are also confirmed through the nitrile functional group (at wavelength $2123.61 \mathrm{~cm}^{-1}$ ) and amide functional group (at wavelength $6136.80 \mathrm{~cm}^{-1}$ ). However, these nitrile and amide functional group were not present in $\mathrm{Gd}_{2} \mathrm{O}_{2} \mathrm{CO}_{3}$ compound as there is no use of nitrogen in the preparation of these compounds. The reaction of $\mathrm{Gd}_{2} \mathrm{O}_{2} \mathrm{CO}_{3}$ and $\mathrm{HNO}_{3}$ is shown in equation (1).

$$
\mathrm{Gd}_{2} \mathrm{O}_{2} \mathrm{CO}_{3}+6 \mathrm{HNO}_{3} \rightarrow 2 \mathrm{Gd}\left(\mathrm{NO}_{3}\right)_{3}+3 \mathrm{H}_{2} \mathrm{O}+\mathrm{CO}_{2}
$$

Before the synthesis and encapsulation of gadolinium(III) in the vesicle, 1-decanol and sodium N-lauroylsarcosinate hydrate were also characterized using FTIR. The spectrum of 1-decanol and sodium N-lauroylsarcosinate hydrate (SNLS) is shown in Figure 3. The chemical bonds and functional group present in the compound are listed as in Table 2.

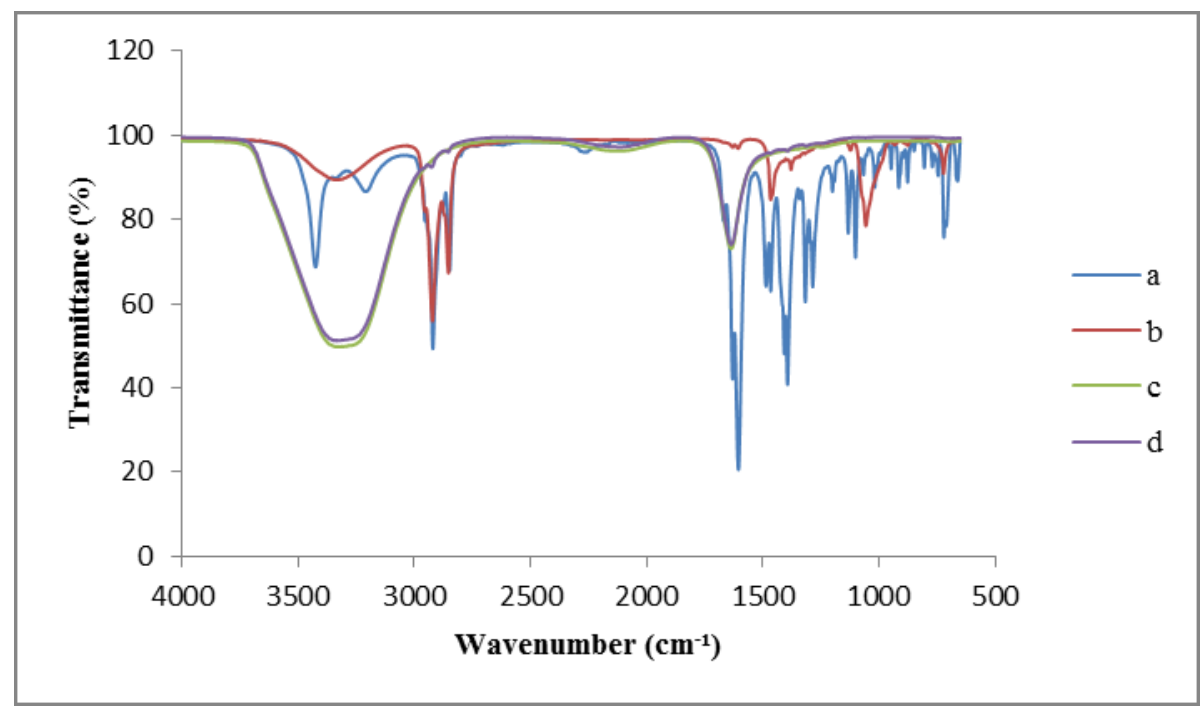

Figure 3. FTIR spectrum of (a) sodium N-lauroylsarcosinate hydrate, (b) 1-decanol, (c) gadolinium (III) nitrate solution and (d) vesicle solution. 
Table 2. Vibrational mode assignment of sodium N-lauroylsarcosinate hydrate, 1-decanol, gadolinium (III) nitrate solution and vesicle solution

\begin{tabular}{llcccc}
\hline \multirow{2}{*}{ Modes of vibration } & Functional & \multicolumn{4}{c}{ Wavenumber $\left(\mathbf{c m}^{-\mathbf{1}}\right)$} \\
\cline { 3 - 6 } & Group & SNLS & 1-Decanol & Gd(NO $\mathbf{N O}_{\mathbf{3}} \mathbf{3}_{\mathbf{3}}$ & Vesicle \\
\hline O-H stretch (wide, strong) & Hydroxyl & 3425.37 & 3341.79 & 3330.65 & 3340.40 \\
C=C-H asymmetric stretch & Alkenes & 3210.79 & n.d & n.d & n.d \\
H-C-H symmetric and asymmetric stretch & Alkanes & 2920.67 & 2922.26 & n.d & n.d \\
C-H bend & Alkanes & 1465.36 & 1465.79 & n.d & n.d \\
C-N stretch & Aliphatic amines & n.d & 1056.42 & n.d & n.d \\
\hline
\end{tabular}

${ }^{\text {n.d }}$ Not detected

The strong and wide peak at $3500-3200 \mathrm{~cm}^{-1}$ represent the $\mathrm{O}-\mathrm{H}$ stretch from the alcohol group of decanol. Based on the modes of vibration in Table 2, the wavenumber of hydroxyl group for sodium N-lauroylsarcosinate hydrate (SNLS) is $3425.37 \mathrm{~cm}^{-1}$ and $3341.79 \mathrm{~cm}^{-1}$ for 1-decanol. The formation of vesicle from mixing of SNLS and 1decanol at molar ratio of 1:2 is confirmed through the present of strong and wide hydrogen bonding at the wavenumber $3340.40 \mathrm{~cm}^{-1}$. Besides that, it is observed that there is a weak mode of asymmetric and symmetric stretch on the methyl group of SNLS and 1-decanol at peak of $2920.67 \mathrm{~cm}^{-1}$ and $2922.26 \mathrm{~cm}^{-1}$.

In the vesicle formation, strong hydrogen bond occurs between SNLS and 1-decanol. The schematic diagram for interaction between SNLS and 1-decanol is as shown in Figure 4 [15]. The amphiphilic molecules consist of a hydrophilic polar head and hydrophobic non-polar tail [16], which tend to form different structures when environmental changes occur. The nitrogen group also contributes to the formation of vesicles. Since the molecular geometry for nitrogen group is trigonal pyramidal is an evidence for the interaction of strong hydrogen bond which occurs between one SNLS molecule and two decanol molecules. The arrangement of surfactants in the vesicle formed between the interaction of SNLS and decanol in aqueous medium can be seen in Figure 5, in which the hydrophobic tail of surfactants is shielded from aqueous medium whereas the hydrophilic head is in full contact with the medium. Thus, a bilayer structure of vesicle is formed.

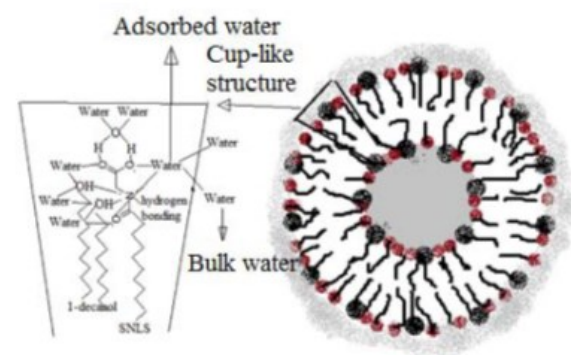

Figure 4. Schematic diagram of hydrogen bonding formation between sodium N-lauroylsarcosinate hydrate (SNLS) and 1-decanol [15] to form a vesicle 


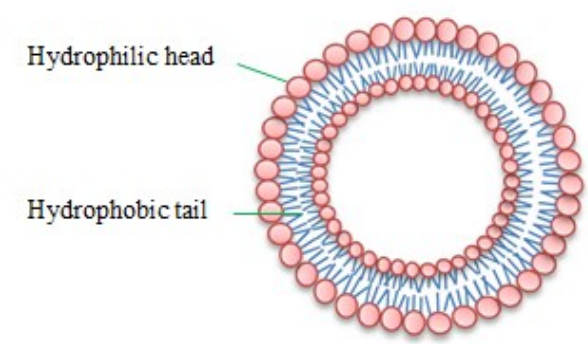

Figure 5. Bilayer structure of vesicle formed through the arrangement of amphiphile surfactants (SNLS and 1decanol) in aqueous medium

The FTIR spectrum of encapsulated gadolinium(III) nitrate in the vesicle is shown in Figure 6. From the FTIR spectrum, the wavenumber $3500-3200 \mathrm{~cm}^{-1}$ represent the strong stretch of $\mathrm{O}-\mathrm{H}$ bond in all samples. In the vesicle encapsulating gadolinium(III) nitrate nanoparticle spectrum, it is observed that there is a slight shift in the $\mathrm{O}-\mathrm{H}$ bond peak in comparison to the control vesicle and gadolinium(III) nitrate FTIR spectrum. The shift of O-H bond is possibly attributed by the attachment of gadolinium(III) nitrate on the $\mathrm{OH}$ group [17]. Besides that, the shift in the peak of gadolinium(III) nitrate nanoparticle was suspected to be encapsulated in the amino acid based vesicles. Further analysis on the morphology of both control vesicle and vesicle encapsulating gadolinium(III) nitrate nanoparticle could be obtained from the transmission electron microscopy (TEM) characterization.

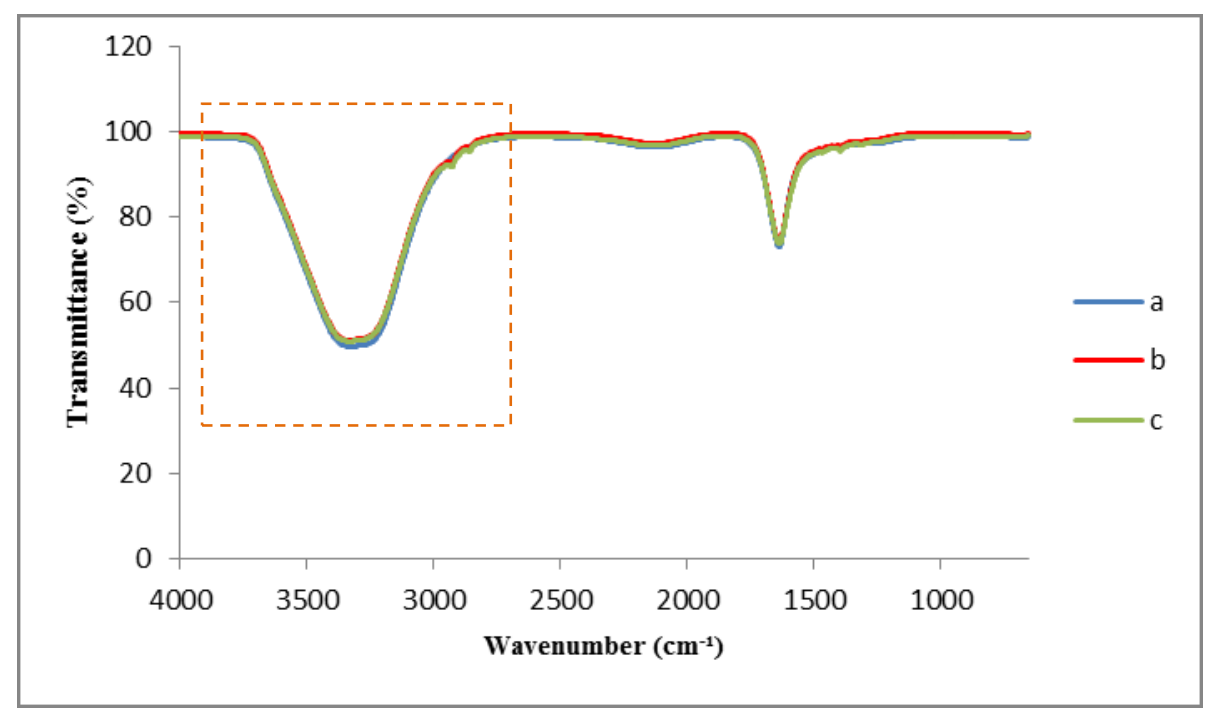

Figure 6. The FTIR spectrum (a) gadolinium(III) nitrate, (b) control vesicle and (c) vesicle encapsulating gadolinium (III) nitrate nanoparticle

\section{Transmission electron microscopy}

The morphology of synthesized vesicle and its size can be seen in Figure 7. From the TEM images, it is clearly shown that the control vesicle and vesicle encapsulating gadolinium(III) nitrate nanoparticle were formed through the spherical images of vesicle. The size of control vesicle ranged between $70 \mathrm{~nm}$ to $200 \mathrm{~nm}$. Whereas, the size of vesicle encapsulating gadolinium nanoparticles ranged between $150 \mathrm{~nm}$ to $250 \mathrm{~nm}$ in diameter. 

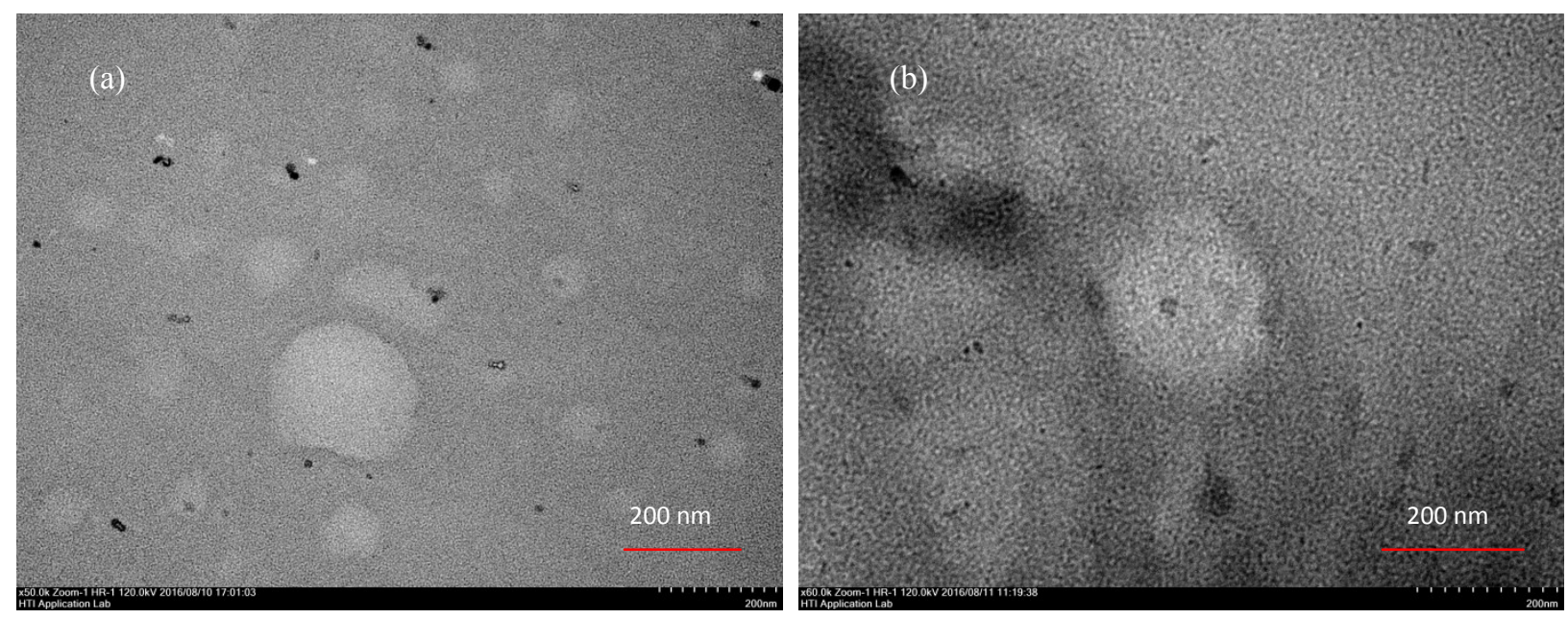

Figure 7. TEM micrograph shows the formation of (a) control vesicle and (b) vesicle encapsulating gadolinium(III) nitrate nanoparticle

Figure 8 shows the morphology of vesicle encapsulating gadolinium(III) nitrate nanoparticles which were stored for two weeks. A globular shape with a size of approximately $3 \mu \mathrm{m}$ was observed. This shows that probably the synthesized vesicle is not suitable for storage and must be utilized directly after synthesized. This can only be further confirmed through stability test based on zeta potential using dynamic light scattering, which is currently on going.

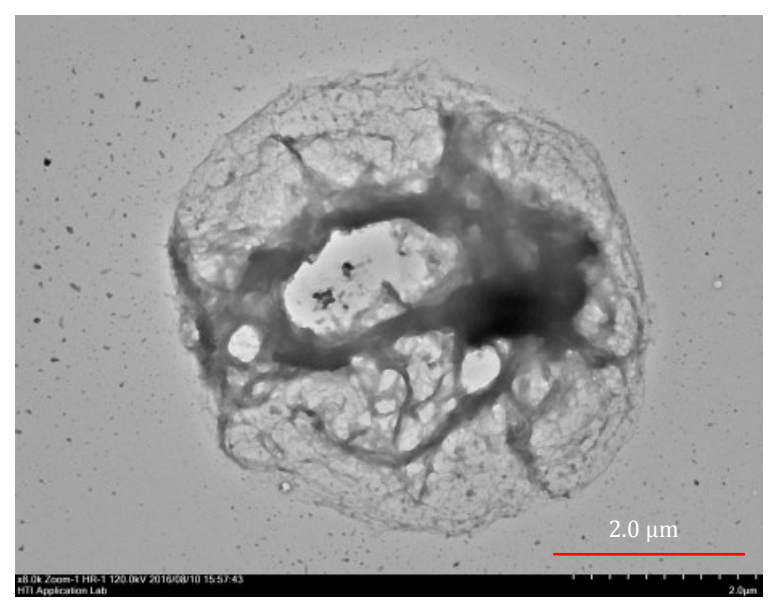

Figure 8. The globular shape was formed after vesicle encapsulating of gadolinium(III) nitrate nanoparticles was stored for two weeks,

\section{Conclusion}

Through this study, vesicle encapsulating gadolinium(III) nitrate nanoparticles was synthesized using sonication method. Through chemical molecular conformation and morphological characterization, it is proven that gadolinium(III) nitrate nanoparticles is encapsulated in vesicle. Therefore, this shows that the surfactant used in forming vesicle can be utilized in drug delivery, specifically in carrying encapsulated gadolinium(III) nanoparticle for medical purposes. 


\section{Acknowledgement}

The work was financially supported by the Fundamental Research Grant Scheme (FRGS/2/2014/SG02/UKM/02/1) and University Research Grant (GUP-2016-015). The author thanks the staffs of the Microscope unit and CRIM of National University of Malaysia (UKM) for their assistance in obtaining the TEM, FTIR and XRD images.

\section{References}

1. Hall, J. B., Dobrovolskaia, M. A., Patri, A. K. and McNeil, S. E. (2007). Characterization of nanoparticles for therapeutics. Future Medicine, 2(6): 789 - 803.

2. Cheow, W. S. and Hadinoto, K. (2011). Factors affecting drug encapsulation and stability of lipid-polymer hybrid nanoparticles. Colloids and Surfaces B: Biointerfaces, 85(2): 214 - 220.

3. Lussier, J. N., Klemer, D. R., Hawthorn, P. S. and Sobottke, M. D. (1995). Gadolinium vanadate laser. U.S. Patent No. 5,420,876.

4. Kleinlogel, C. and Gauckler, L. (2000). Mixed electronic-ionic conductivity of cobalt doped cerium gadolinium oxide. Journal of Electroceramics, 5(3): 231 - 243.

5. Sondermann, T. (1981). Method for manufacturing gadolinium-containing nuclear fuels. U.S. Patent No. 4,278,560.

6. Bernhard, E. J., Mitchell, J. B., Deen, D., Cardell, M., Rosenthal, D. I. and Brown, J. M. (2000). Re-evaluating gadolinium(III) texaphyrin as a radiosensitizing agent. Cancer Research, 60(1): 86 - 91.

7. Aisen, A. M., Martel, W., Braunstein, E. M., McMillin, K. I., Phillips, W. A. and Kling, T. (1986). MRI and CT evaluation of primary bone and soft-tissue tumors. American Journal of Roentgenology, 146(4): 749 - 756.

8. Park, J.-A., Kim, H.-K., Kim, J.-H., Jeong, S.-W., Jung, J.-C., Lee, G.-H. and Kim, T.-J. (2010). Gold nanoparticles functionalized by gadolinium-DTPA conjugate of cysteine as a multimodal bioimaging agent. Bioorganic \& Medicinal Chemistry Letters, 20(7): 2287 - 2291.

9. Lux, F., Sancey, L., Bianchi, A., Crémillieux, Y., Roux, S. and Tillement, O. (2015). Gadolinium-based nanoparticles for theranostic MRI-radiosensitization. Nanomedicine, 10(11): 1801 - 1815.

10. Szoka Jr, F. and Papahadjopoulos, D. (1980). Comparative properties and methods of preparation of lipid vesicles (liposomes). Annual Review of Biophysics and Bioengineering, 9(1): 467 - 508.

11. Zhu, T. F. and Szostak, J. W. (2011). Exploding vesicles. Journal of Systems Chemistry, $2(1): 4$ - 10.

12. Sankar, V., Ruckmani, K., Jailani, S., Ganesan, K. S. and Sharavanan, S. (2009). Niosome drug delivery system: Advances and medical applications an overview. Pharmacol Online, 2: 926 - 932.

13. Rosli, M., Alia, N. R., Mohamed, F. K. K., Sah, M., Syafiq, M. A. and Rahman, I. A. (2014). Effect of gamma radiation on amino acid based vesicle carrying radiosensitizer. Malaysian Journal of Analytical Sciences, 18(3): 555 - 561.

14. Cevc, G. (2004). Lipid vesicles and other colloids as drug carriers on the skin. Advanced Drug Delivery Reviews, 56(5): 675 - 711.

15. Akter, N., Mohamed, F., Radiman, S. and Reza, M. I. (2012). Vesicles and lamella: Outcome of the changing formation path of a sodium N-lauroylsarcosinate hydrate/1-decanol/water system. Nature Precedings, $2012: 1$ 18.

16. Yamamoto, S., Maruyama, Y. and Hyodo, S. A. (2002). Dissipative particle dynamics study of spontaneous vesicle formation of amphiphilic molecules. The Journal of Chemical Physics, 116(13): 5842 - 5849.

17. Lim, S.-F., Zheng, Y.-M., Zou, S.-W. and Chen, J. P. (2008). Characterization of copper adsorption onto an alginate encapsulated magnetic sorbent by a combined FT-IR, XPS, and mathematical modeling study. Environmental Science \& Technology, 42(7): 2551 - 2556. 